\title{
Perspectives on scale in participatory spatial planning
}

\begin{abstract}
This article examines the role of scale in participatory spatial planning, in response to arguments about the inclusivity of different scales of urban governance, and offers a case study from the UK. The article draws on participatory spatial planning literature, where scale is understood to be bound up with institutional and communicative power. Existing literature on public involvement in planning has given insights into the ways that scale relates to conflicting rationalities of public involvement and empowerment. Those works also suggest that for participatory planning, understandings of scale are constructed around notions of 'shared interests'. Using empirical data from formal public participation in sub-regional strategy-making England, the article unpacks understandings of scale and how they are constructed within the context and content of the case. Findings suggest that scales of shared interests and scales of desired action did not align, but participants could challenge or reify scales of authority in their demands for spatial justice.
\end{abstract}

\section{Introduction}

Scale is a matter of increasing importance for participatory governance, and there are particular concerns about the perspectives of local people and planners in relation to spatial planning. This article engages with current debates over scale and offers new empirical analysis, with a focus on making spatial strategies. Scalar expectations of public voice have real power in debates on urban governance, and recent events have shown how they can shape public views. In the UK, scale of governance has been a lightning rod for political conflicts, focusing attention on planning decisions (Cowell, 2017; Natarajan, 2018). However, as argued here, such conflicts result from false assumptions about the relationship between public participation and scale of spatial planning.

A basic premise of public involvement in planning (since Healey 1997) is that collaborating with stakeholders will produce 'relational value' for planning, which is to say that decisions may be coproduced and relationships of governance networks strengthened through 'communicative work'. This is supported by a wealth of research into spatial planning that has demonstrated how 'dialogic interactions' can build relationships and introduce new forms of knowledge, particularly local 
knowledge (Beebeejaun, 2016; Curry, 2012; Lee et al., 2013; Natarajan, 2017 to list but a few). In Europe people who are likely to be affected by environmental change have certain legal rights to participation (UNECE, 1998), and as argued elsewhere in this special issue, exchanges between statutory decision makers and the general public can also foment citizenship (Baltazar et al. 2019) and cement a more participatory democracy (Bouche-Florin, 2019). In short, the involvement of citizens is expected to contribute substantively to the work of participatory spatial governance. However, as this article proposes, conflict and uncertainty about the role of scale may hinder the search for meaningful engagement with spatial planning.

Scale has become highly politicized in debates about participatory urban governance. The local appears to be politically prioritized in the UK. In England the narrative of Localism has been used to suggest that planning ought to be delivered at a smaller scale in order to better engage with public concerns. The following quote, taken from the website of the UK government's department with responsibility for planning, exemplifies the claims made about public voice at the lowest scale of spatial strategy. "Neighbourhood planning replaces top down regional planning, ending the planning resentment that stops the homes, businesses and facilities people want being built. It gives communities a new role and strong voice in local planning." (DCLG, 2013) By contrast, in Wales devolutionary arguments for a national public voice have led to spatial strategy-making powers at the Welsh 'regional' scale (Cowell, 2017; Natarajan, 2018). In such cases, the 'vertical working of territorial scales' (Allmendinger and Haughton, 2007, 2010) is driven by an assumed relationship between scale of governance and delivery of public voice.

The connections made between geographical scope and procedural legitimacy reference notions of public voice, but they conflict with theories of participatory spatial planning. Firstly, is suggested that scale of authority might help to empower publics, but the logic behind this is not clear. There may be practical benefits of downwards rescaling if it is less onerous for people to be involved in local planning processes than in national ones. But it does not necessarily follow that the scale of spatial strategy being geographically 'close to the public' might support meaningful engagement. In addition, as will be explained in more detail later on, the notion of an existing scale of public voice suggests a Cartesian assumption about locality that does not align well with the epistemology of participatory spatial planning (Healey, 1996; Innes, 1995), which is rooted in the idea of discursive constructions of knowledge 
about places. Likewise, studies of spatial policy networks strongly suggest that scale ought to be an outcome rather than a determinant of communicative exchanges between spatial planners and the public.

In light of the discussion above, this article focuses on understandings of scale within statutory strategy-making, where the public is involved through dialogue. The research has three premises: that it remains critical to ensure public involvement in planning (Brownill and Parker, 2010); that there will be diversity within any 'public voice' (Beebeejaun, 2006); and that the argument against the 'NIMBY' framing of local people has been won (Wolsink, 2000). The work reported here has drawn on insights about scale from current participatory planning literature, and an empirical case study from England where perspectives on scale within public engagement with spatial strategy were examined. The case comprises the context, set up and actual exchanges of formal public participation in spatial planning at a new tier between the regional and local statutory scales. The ad hoc scale of spatial strategy provided an instrumental type of case (Baxter and Jack, 2008; Starman, 2013) suitable for testing scale in exchanges with the public; as matters of scale were likely to be more observable than in local planning where understandings of scale might be somewhat 'settled' around an established 'district', and thus not explicit.

The rest of this article is structured as follows. In the next section, the participatory spatial planning literature is reviewed for the lessons on scale. This suggests two points of focus for the research: the reasoning behind participation (participatory rationalities); and how understandings of scale were built (constructions of shared interests). Then the study methods and empirical findings are presented, and the final sections reflect on the findings and offer conclusions for the future of participatory spatial planning.

\section{Scale as a concern for participatory spatial planning}

This study focuses on the role of scale in participatory spatial planning. Current literature on spatial planning is infused with participatory theory, and this section unpacks the lessons on scale. It begins with the rationalities of public involvement in planning, and how scale appears within them. It then turns to prominent concerns over citizen empowerment and how they play into debates on scale of planning. 
Broadly speaking, current spatial planning theory espouses the participation of the public in planning on the basis that it is a normative good that helps legitimize planning and improve outcomes for communities. This is based on widely accepted principles of participation, as a bottom-up, communicative procedural innovation, that moves planning away from practice that is insensitive to particular publics (Forester, 1989). An important distinction is noted by Quick and Feldman (2011), who differentiate between two rationales of engaging publics: inclusionary rationales that that focus on bringing all people into planning processes; and substantive rationales where the focus is on the contributions that people can make ${ }^{i}$. This distinction is significant because the different justifications for participatory planning relate to certain expectations of scale as follows.

Authors who take inclusionary approaches to public involvement in planning tend to emphasize 'ethical duty to the public' in statutory development practice in two ways, both of which implicate scale. Firstly, affected publics are generally framed as 'end-user' (Janssen-Jansen and van der Veen, 2017). Here, it is notable that an ‘impacted population' defines which citizens should be involved. The Aarhus declaration (UNECE, 1998) defines the public with participatory rights more broadly, as "one or more natural or legal persons, and, in accordance with national legislation or practice, their associations, organizations or group", and only bounds in relation to "the public concerned" in relation to "specific activities", which (as listed in Annex I) primarily involve infrastructure and industrial activities for the production and management of energy, metals, mining, water, waste. This gives rise to a default position of involving communities who are 'local to development', particularly when engaging those in the proximity of major infrastructure projects (Natarajan et al., 2018). That is not to say that identifying local impacts of any development is simple, and studies in the UK have demonstrated the complexities involved (Lee, 2017; Rydin et al., 2018a, 2018b). However, the notion of end-user participation frames inclusivity in terms of a locality, and this connects the scale of participatory processes to the scope of direct physical development impacts.

Inclusionary rationales can also espouse a second type of 'ethical duty', which focuses on poorer cohorts or marginalized communities (Fainstein, 2010; Sandercock, 2004). In these approaches, planning is expected to help marginalized social groups and consequently seek to involve specific publics. Importantly, disadvantage or marginality can only be defined relative to some kind of average or benchmark. The 
means of determining that will be based on the area considered, whether national, regional, local or other scale. Again, this presents public involvement as a formal obligation on the state and shapes who is included, this time on the basis of the area for measuring relative disadvantage. The included population is not 'local to development', or at least not necessarily so, but rather 'within an area' that could be much wider than their locality.

Moving on to the 'substantive rationales', authors tend to justify public involvement on the contributions of participants and effects on planning institutions and knowledge. The expectation is that communicative action, through dialogue with new actors, opens up institutional thinking (Douglas, 1987; Forester, 1989, 1999). Dialogue is not presented as the means to uncovering a pre-existing problem or solution, since that there are no such facts ready for discovery (Rittel and Webber, 1973), instead they are seen a means to engaging with the complexity of social phenomena (Innes and Booher, 2010). This has led to expectations of social learning in planning (Bond and Thompson-Fawcett, 2007; Holden, 2008; Wang, 2015) in order to engage with social realities that are continually being redefined. The idea is that diverse social values can be brought to the fore and new understandings of problems are constructed, with the ultimate goal that planning solutions might be 'coproduced'. Here, it is important to acknowledge critiques of the dialogic mode of decision-making, and the impossibility of 'complete consensus' (Hillier, 2003).

The underlying argument behind substantive rationales for participation, that planning should be the site of social learning, has implications for scale. The argument runs that spatial planning must take account of both social and spatial dimensions of complexity, because places defy definition (Healey, 2007, 2010) or ideas of territory are in flux (Rozema, 2015). In turn, this implies that scale is a subject of spatial planning, and a socially constructed phenomenon, that is brought to light deliberation and dialogue. Again it is important to acknowledge the critiques of “endless openness" (Campbell and Marshall, 2002) where social learning is an endless cycle of challenge to plans.

The inclusive and substantive rationalities of public involvement both argue that participation can improve how planning can respond to people's needs, but the different approaches mean that (tacitly) they treat scale differently (Figure 1). Inclusive rationalities contain ethical justifications for involving people on the basis that they may be impacted by development, or that they might be at some kind of 
disadvantage. Both of those justifications suggest that there are 'knowable' localities, which could determine a relevant public who might be involved. The implication is that there is existing knowledge of people's interests that relate to a geographical area, and that scale for planning is 'fixed' in relation to the impacts of development or the distribution of socio-economic benefits. By contrast, substantive justifications for participation suggest that planning matters are socially constructed, and is likely to be complex. In this approach, scale is product of participatory process, through dialogue with diverse publics who can't necessarily be specified in advance.

Scale pre-established Scale constructed

Scale $=$ ?

\section{Figure 1: Rationalities and scale in participatory planning (Source: author)}

In both rationalities, whether inclusive or substantive, the matter of who should be involved is determined by a notion of 'shared interests' of those who participate. Interests are shared by citizens participating in planning for an area where people might be vulnerable, and scale is the expression of 'their' area. This echoes 
Dewey's definition (1927) of 'the public interest', where social problems necessarily existed and those problems called up 'a public' with shared interests that the state might serve. The full scope of subsequent debates and ongoing work on the public interest in planning (Slade et al., 2019) is beyond the scope of this article, but Dewey's lens is helpful here. It suggests interest formation is inherently intersubjective or based on commonly shared understandings (Lennon, 2016), and the implication is that a shared interest exists in the ability to 'act publicly' (Tait, 2016), such as creating a spatial policy or any other state intervention. Building on that, an understanding of a shared interest needs to be built for each moment of statutory action. As Tait puts it collective preferences are rooted in shared understandings of the consequences of particular (in)actions in context (Tait, 2011). Therefore, a notion of 'shared interests' underpins rationalities of participation in planning, and these suggest a constructed view of scale.

The literature reviewed so far suggests that the two rationalities of participation, the inclusive and the substantive, both anticipate shared interests but have divergent expectations of scale. Across the literature, as shown in Figure 1, scale has been (tacitly) framed as the determinant and the outcome of participation. Depending on the rationality employed, scale is either knowable through (albeit contested) development impacts or it needs to be socially constructed. When it comes to participatory planning, the main concern about any such 'grey area' is whether or not it can empower citizens.

\section{Methods}

The rest of this article presents and reflects on an empirical case from England. As guided by the literature, the study of scale looks at the context, set up and content of actual exchanges within formal public participation in spatial planning, and the focus of attention is the construction of shared interests. The case was selected purposively (Baxter and Jack, 2008; Starman, 2013) for its more unusual scale of authority, which was neither local nor regional. As noted earlier the meanings and uses of scale might be more readily observable in such a case, as they would be less likely to have become tacit understandings. The study is rooted in the interpretive qualitative mode of research, where the focus is on meanings and behaviours rather than hypotheses and causality, which is helpful for studies of 'human action' in planning (see Flyvbjerg, 2001 for a fuller explanation). This section describes the approach to data 
collection and analysis.

The empirical data comes from a case of public participation in plan-making by a planning authority for the sub-region of North Northamptonshire, as part of its work to produce a revised Joint Core Strategyii. Planners were seconded from four local authorities into an ad hoc 'Joint Planning Unit' (JPU) for a sub-region. Members of the public were involved via an online questionnaire and a 'roadshow', where they had face-to-face exchanges with the planners. The participatory exercises were run across the whole sub-region over a six-week period early in 2011. The author was 'embedded', helping to run events and manage the online survey. Data was gathered from publicly available planning records, the online survey, and field records hand written by the author with informed consent. All data was anonymized before analysis to leave only indicators of location and demographics.

The study necessarily takes a situated approach to public participation, rejecting the notion of 'supposed universal applicability' where "planning can occur in a vacuum free of contingency" (Lennon, 2016, p. 5). In the Western European context, there are generally formal participatory obligations on authorities at the planmaking stage and a range of participatory modes can be used. Those studied here were typical of strategic spatial planning practice in the UK during the early years of this century (Baker et al., 2010). Strategy-making is also readily distinguished from the regulatory stage in the UK, since policy and consenting have different processes (Janin Rivolin, 2008). This means that the results speak to the role of scale in policymaking and give in-depth focus on scale within the construction of knowledge, but there are limits to their applicability. That is to say that the findings cannot be extended to matters of eventual delivery. In addition, findings from this study will need to be treated with caution in relation to minority or marginalized populations, in view of warnings over the exclusionary potential of 'invited spaces' (Cornwall, 2004; Cornwall and Coelho, 2006; Miraftab, 2004).

To ensure rigour, the analysis drew on the concepts from the literature for coding and used standard qualitative methods of data reduction (Denzin and Lincoln, 2000; Fereday and Muir-cochrane, 2006). It used themes of shared interests, social construction, and rationale of public involvement, and examined the context (both the organizational culture and participatory processes employed) and the content (from online and face-to-face exchanges) across all datapoints (background records, events, survey data). Findings from the analysis are presented in the next section. 


\section{A case study of scale within public engagement}

As set out here, the North Northamptonshire Joint Planning Unit was responsible for a joint core strategy, which would provide a single spatial policy to guide development across four local authorities. In effect, this proposed a shared interest for the combined authority area, and public participation was conducted across the subregion. However, analysis of the context and content of public involvement brought to light a range of spatially defined interests, which reflect the themes of the literature reviewed above to varying extents, as follows.

\section{Context}

The North Northamptonshire Strategy (the Strategy) was intended to provide shared policy for matter such as housing allocations, employment strategies, investment in transport and infrastructure. The Strategy applied to four districts in a 'sub-region' within the then 'East Midlands' region of England, an area totalling 986 $\mathrm{km}^{2}$. This spatial plan would guide the regulatory decisions taken by each of the four local authorities, Corby, East Northamptonshire, Kettering and Wellingborough, to serve an overall sub-regional interest. The North Northamptonshire Joint Planning Unit (the Unit) was established by the councilors who were the statutory representatives at the local scale. The new ad hoc policy making was rooted in formal democratic channels of accountability, but not neatly aligned with the "continual institutional becoming' noted in participatory spatial planning theory (Albrechts, 2013). The shared interest was proposed by planners rather than constructed by the public, as seen in civic activism or co-productive models (Watson, 2014).

The driver for the Strategy was the concerns of Government actors about planning for growth. Statistics for the ten years to 2011 demonstrated that the local population had expanded by $11 \%$ in the period (from 285,600 to 316,800 ). At the time of the study, the towns of Corby, Kettering, and Wellingborough were earmarked by central government as 'growth areas', for which regional policy would encourage economic and population expansion (Office of Deputy Prime Minister, 2003) ) $^{\mathrm{iii}}$. Accordingly the Strategy focused on managing increased development across settlements. Joint policy for the four districts aimed to strengthen 'functional connections' between urban areas and more rural areas of East Northamptonshire in order to manage expansion. The core diagram for the 2008 strategy (figure 2), 
visualizes this with urban extensions from the core settlements, which are interlocked with a rural spine and green infrastructure.

NORTH NORTHAMPTONSHIRE CORE SPATIAL STRATEGY

FIGURE I0: KEY DIAGRAM

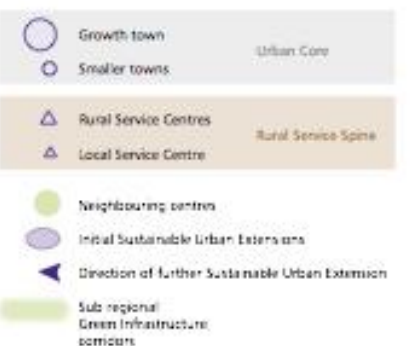

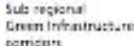

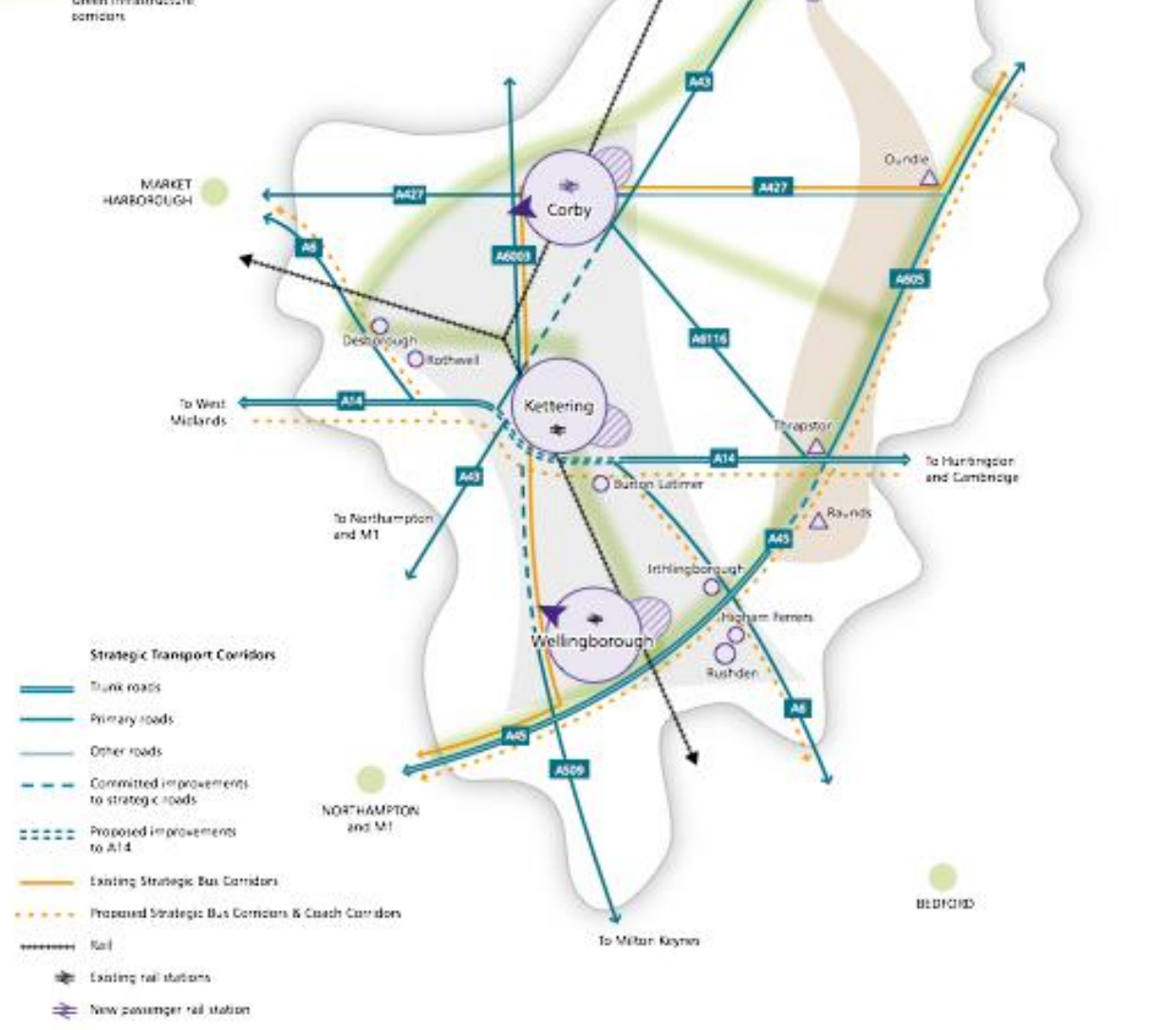

muavernes

Figure 2: Core Strategy Key Diagram (Source: NNJPU) 
The Strategy articulated a sub-regionally shared interest in managing development, in the context of wider growth forces. The governance rationality took an ethical line, in that the combined planning area was justified on the basis of enabling elected statutory decision-makers to manage development in the interests of their constituencies. In such approaches to participatory planning, the population of 'affected' people are identified in respect of their proximity to development. Here, the affected community was the population in urban areas where growth was expected and rural areas around them. Yet the scale seen in the creation of strategic planning capacity, was sub-regional along the boundaries of local authorities.

The initiation of the sub-region can be traced back to a national government proposition of shared interest in spatial policy to better distribute growth. As part of its 'sustainable communities' policy, central government had proposed that growth needed to be distributed better within the nation. This can be seen for instance in the rhetoric of the Office of the Deputy Prime Minister on balancing the national housing market, "In some parts of the country there are still areas of acute deprivation where demand for housing has collapsed. In others, demand for housing continues to outstrip supply, leading to rising house prices and shortages of affordable housing. We need a step change in our approach to tackle these problems. We need to work together to build sustainable communities in which people want to live.” (ODPM, 2003, p. 1) England had no national spatial plan, and so a set of regional and sub-regional strategies were developed in response to the agenda of distributing growth. The strategies would need to conform to policy at 'higher tiers', but each asserted the importance of distribution of growth for their different areas. The Regional Spatial Strategies suggested certain socio-economic interrelationships, and for the East Midlands the most important of those was "the fact that it is strongly influenced by the proximity of major urban centres in adjacent regions" (GOEM, 2009, p. 10).

The interlocking spatial policies across England referenced shared interests at a range of scales in better managing growth. The shared interests were at the scale of the authority, as can be seen in the justifications given for providing policy. Each strategy provided different levels of detail about the growth in housing, infrastructure and socio-economic development and impacts on communities. Regional bodies produced the East Midlands Regional Plan (RSS 8), and the Milton Keynes South Midlands Strategy (MKSM) was classified as a ‘sub-region' and included the whole 
of North Northamptonshire. RSS 8 highlighted the consequences of growth for the East Midlands, such as rising house prices resulting from in-migration, as well as other matters of priority such as flooding caused by climate change (GOEM, 2009, p. 9). For MKSM, an overarching concern was levels of employment and reliance on private transport for commuting within this large sub-regional area (GOSE et al., 2005, p. 8). The Strategy for the smaller sub-regional area of North Northamptonshire developed policy in more detail, for instance on scale and phasing of urban extensions (NNJPU, 2008, p. 45), based on studies of more localized impacts on existing settlements. Together the strategies presented a complex picture of multiple scales of interests. The devolved authorities were responding to the national growth agenda, and articulating interests at different scales. They would rely on the most subsidiary tier for detail of local development strategy, which in this case was the North Northamptonshire joint authority.

In order to help review the Strategy, the Unit conducted public engagement exercises, focused around an online questionnaire and a 'roadshow' across the subregion in February and March 2011. People could answer a set of questions online and 'drop-in' to events to discuss possible revisions to the Strategy (see figure 3), where discussions were wide-ranging. As discussed earlier, arguments for engaging people can go beyond issues of rights to inclusion, and extend to the substantive contributions that the public can bring to planning. These processes associated with social learning and a constructed approach to understanding scale, i.e. rather than relying on fixed boundaries. This was seen to some extent in the set-up of public engagement, which opened up the possibility of introducing the forms of knowledge expected by communicative planning theory (Sager, 2017). The intention was that public input would feed into policy directions on the location and form of development, but this would need to happen within a context where interests and powers were already being framed by scale. 


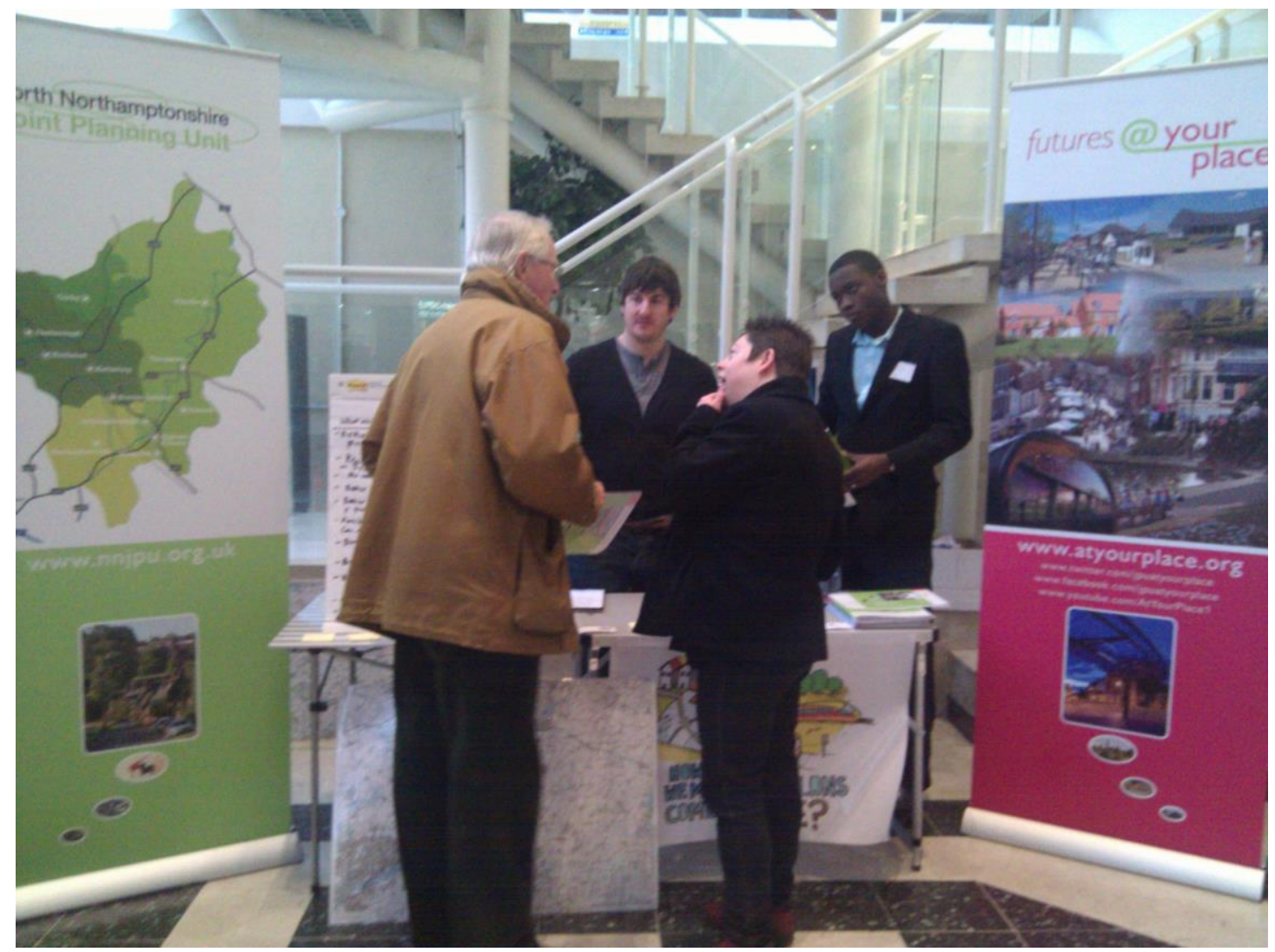

Figure 3: Discussions at a 'drop-in' session (Source: author)

\section{Content}

Exchanges with the public on spatial strategy were in person and via an online survey. For face-to-face dialogue with the public on the Strategy, venues were selected in localities across the sub-region, including both urban and rural areas, for a total of 12 events. As additional means of participation across the sub-region there was an online questionnaire. The planners from the Unit presented Strategy content and possible revision options in person at events. They also produced and distributed over 1500 copies of a document (see figure 4) containing a series of maps of the plans, and potential developments. While the drop-in nature of the roadshow event prevented accurate counts of participants, observation and records demonstrated that all of the key issues were discussed with local people at each venue, and over 190 written responses to the survey were received. 


\section{futures@your}

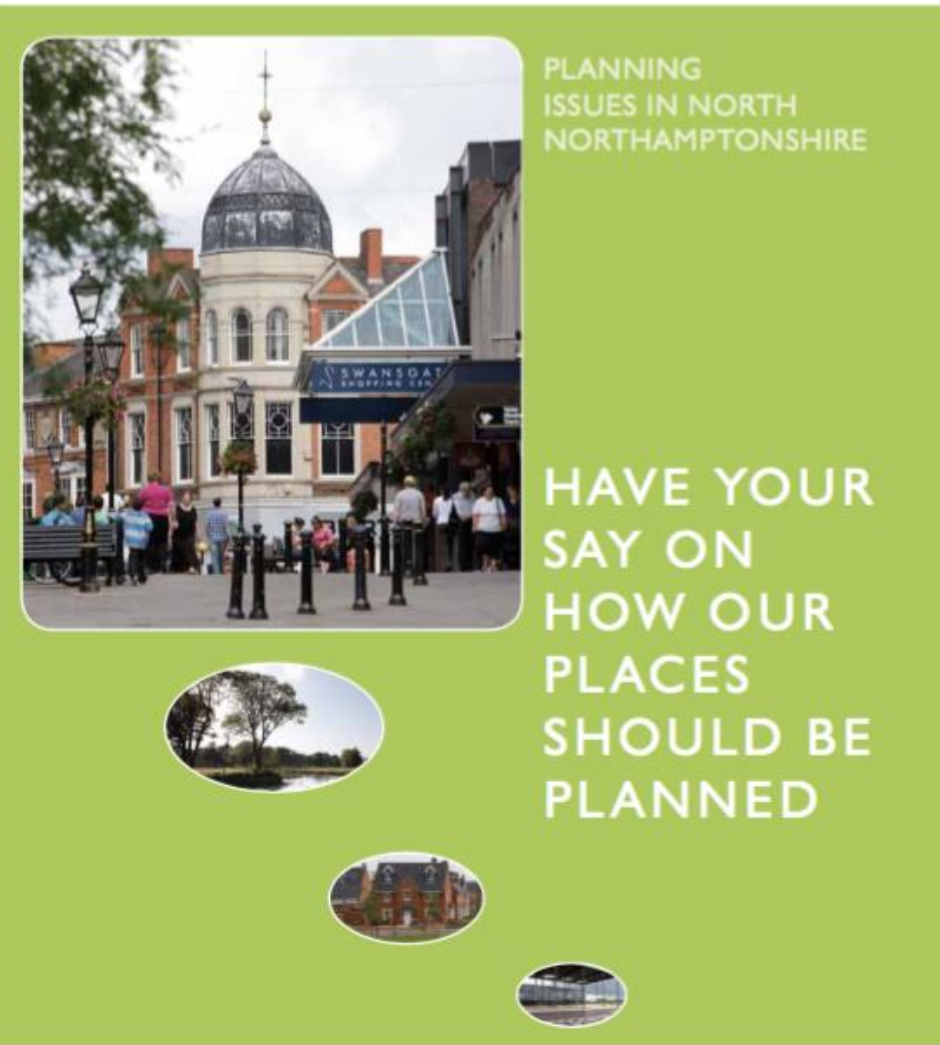

PUBLISHED BY

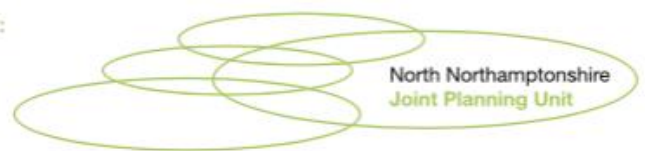

JANUARY 201 1

TOWARDS A NEW JOINT CORE STRATEGY

Figure 4: Cover of report for public consultation (Source: author)

The main intention of sub-regional outreach was to discuss growth patterns, and dialogue centered on the problems experienced locally, and planning strategy in light of that. The Unit approached each locality as a discrete entity to be considered in its own right, which was evident in the line of questioning. Planners introduced the proposed sub-regional options but followed up by asking about the concerns and aspirations of a particular village or town. Similarly the questionnaire asked for instance about local perspectives on housing targets for North Northamptonshire saying, 'From your own point of view, what would make additional housing acceptable?' In the ensuing face-to-face and online exchanges about 'what was 
needed locally' and the sub-regional Strategy, there were some common approaches to construction of shared interests and scale.

Members of the public who participated in the roadshow and the survey overwhelmingly approached matters in relation to 'local community', as they shared their views and experiences. People often described issues that affected a specific group within their locality, and it was particularly striking that they often spoke of 'other' groups, i.e. rather than the group to which they themselves belonged. For instance older people would comment on how expensive housing in the area was for young people (in Kettering), employed people were concerned about the difficulties for graduates in finding skilled employment (Corby). This suggests that people's interests in the Strategy emanated from their membership of a community, and the value to them of the overall wellbeing of the community. More significantly for the study of scale, although discussions were initiated by a proposed 'local need' (inherent in the set-up of public engagement) they went beyond a 'directly local' notion of community. Typically people noted the importance of developing facilities to serve the wider population surrounding their own settlement, such as a hospital in Wellingborough serving people in that town and beyond it (see figure 5). For members of the public the relevance of such interconnections was a local interest mirrored in and supported by other communities. They rooted the connections in local experiential knowledge, as anticipated by work on social learning (Holden, 2008). It is important to recognize that people were being engaged as individuals in a locality, rather than as members of a civil society organization (e.g. local amenity society or environmental interest group), and they may have responded differently in another context. Nonetheless, participants in this case voiced community values as literature anticipated. 


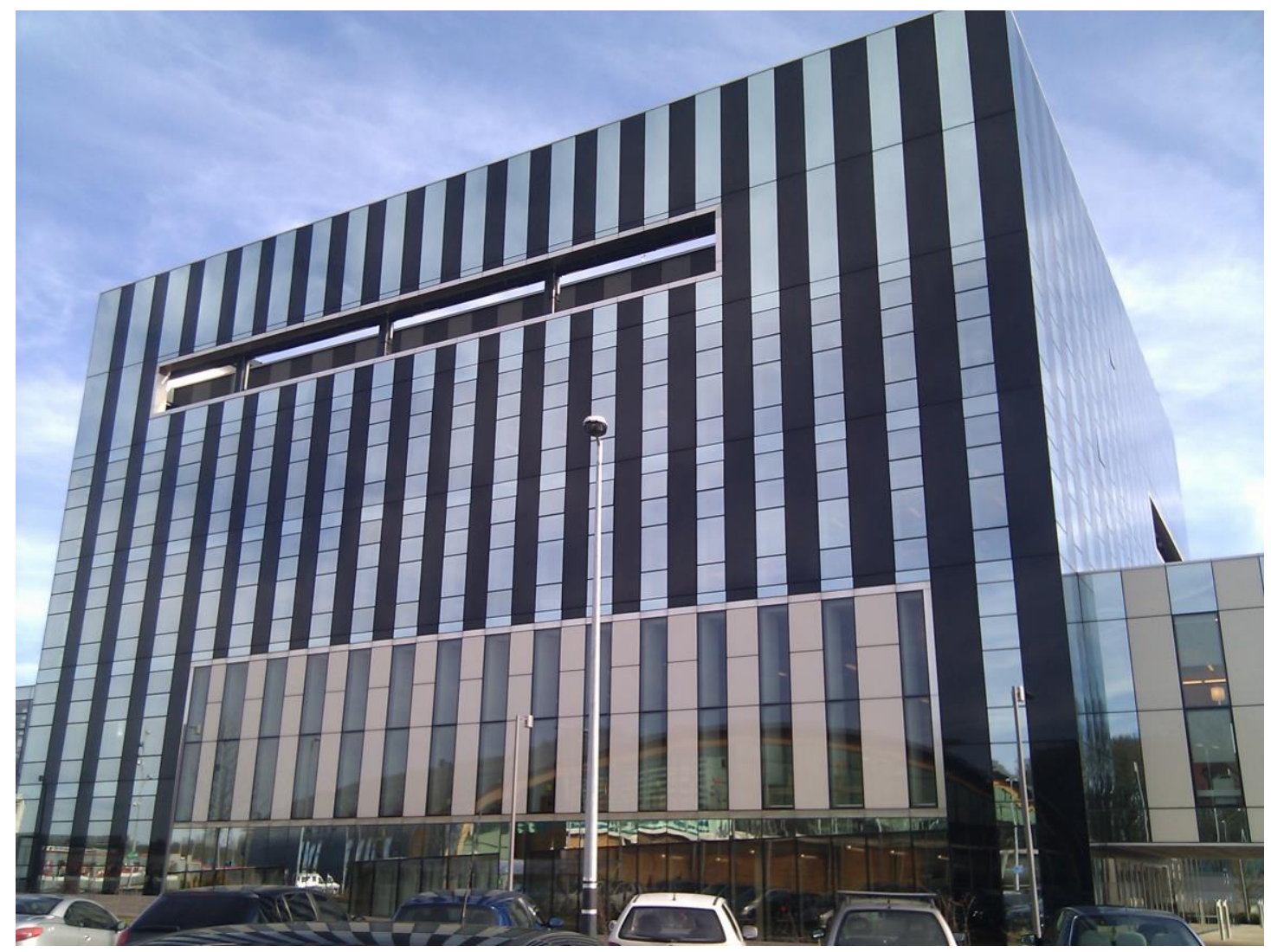

Figure 5: The 'Corby cube’ with public leisure facilities (Source: author)

Looking in more detail at the construction of scale, participants were mainly discussing local issues and building outwards from lived experience. Although a community might see itself at a relatively small scale, people approach 'local issues' more broadly, thinking about how they would impact other settlements, and rural hinterlands. Significantly, communities outside the Strategy area boundary were considered, which demonstrated that the relevant place was not constructed within narrow geographic or administrative bounds. For instance in the small town of Irthlingborough, people discussed how their community needed "better access to the countryside for older people and non-car users", which suggested the issue of their community extended outside the settlement boundaries. Thus, as anticipated by communicative theories, people did not reference to rigid or formal boundaries, such as town, district, or political constituency. The scale of any issue was generally constructed as wider than residential due to the 'lived experience' perspective. For instance, daily interactions with other settlements were often important in discussions about how to deal with the issue of employment. In an example from Higham Ferrers, locals emphasized that the employment opportunities in nearby Raunds were 
extremely important to them. This suggested the strategy should include the settlement of the community and wider connected areas.

Where scale was socially constructed in this community-oriented way, the resulting expectations of strategy could be in tension with the statutory context. Understandings of scale were co-constructed between planners and citizens, by starting with questions about local need and expanding outwards with local knowledge. For instance, illegal parking in Irthlingborough was related to heavy lorry traffic produced by the prevalent logistics industry in the Midlands (see rural traffic in figure 6). Lessons from participation in an informal context have already demonstrated how planning action by grassroots actors needs to be built 'upwards' (Watson, 2014). However, in this case regional and sub-regional authorities had established their boundaries, which seemed to limit the flexibility of scale. While discussions of local need could implicate areas outside of the formal geographical limits of institutional context, the strategy could not directly address them. This is not to suggest that there might not have been 'softer' ways for the planners or indeed the public to try to tackle the issues, for instance through negotiation with other authorities, however the formal powers were limited. Local issues could be caused by activities in places outside the area of the Strategy, and therefore even if protective provisions could be offered there would not be the option to tackle root causes via spatial policy. The implications of this are discussed in the next section. 


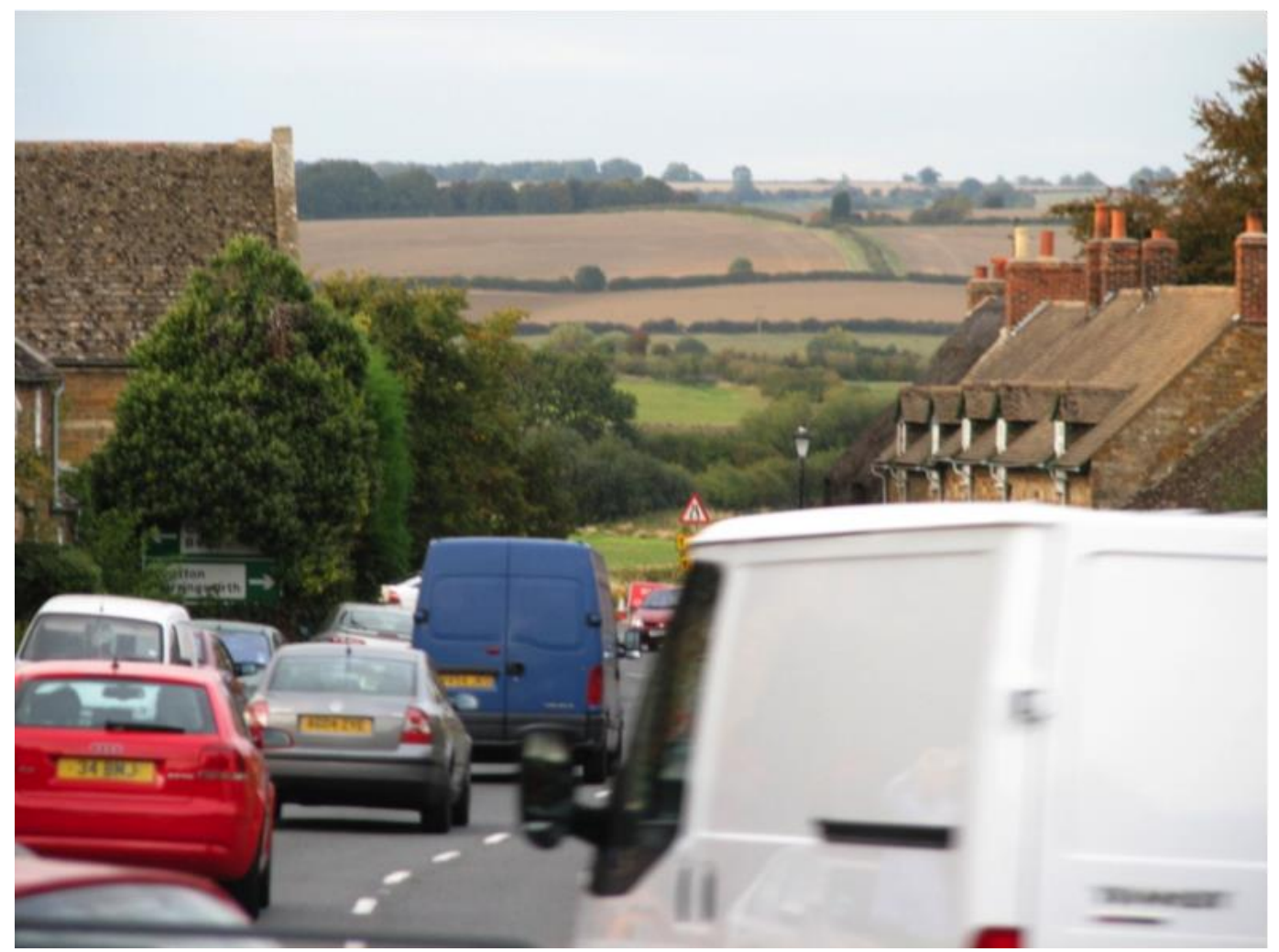

Figure 6: Rural traffic in North Northamptonshire (Source: author)

Some exchanges were oriented more towards North Northamptonshire and the possibility of sub-regional growth. In those instances, citizens overwhelmingly drew on arguments about fairness, in terms of the spread across the area of investments, facilities and new housing. Housing development was particularly contentious, with comments like "Desborough is overloaded with housing". People discussed benefits that had accrued to different settlements, and would typically advocate for their (smaller scale) communities, highlighting where larger settlements had already received investment. This was recorded in the planners' records as, "Disparity in funding received by Rushden in comparison to Higham Ferrers was raised, particularly at the Higham Ferrers consultation road show". In Rushden, the main town in East Northamptonshire, people noted "general lack of retailing compared to [the larger towns of] Corby/Wellingborough", while in Higham Ferrers (another East Northamptonshire town) people perceived that investments had 'unevenly' gone to Rushden. The planning context was clearly a significant factor shaping the conversations, and the Strategy directed discussions towards patterns of development across the sub-region. Nonetheless, people from each locality argued that sub-regional growth would be conditional on meeting local community's needs, and this held true 
whether they were for or against the principle of growth. In these exchanges, justice was seen as fairness of investment within the sub-region. This could be taken as suggesting a shared interest at the regional scale, which would legitimize the work of the Unit. However, the participatory space was limited to what might be described as invited space (Cornwall, 2004; Cornwall and Coelho, 2006; Miraftab, 2004), and it should be recalled that the public was reacting to a proposed interest. Indeed, most of the participating public were unfamiliar with the authority, for instance asking to examine the map of the North Northamptonshire area at events, and more accustomed to interacting with Local Authorities. Nonetheless, people focused on the principle of a duty of statutory bodies to ensure distributional fairness for all communities in their area.

The analysis presented so far shows how exchanges were predominantly focused on local community interests, even where they engaged with the issue of subregional distribution. However, an interesting anomaly was seen in response to the 'North Londonshire campaign'. This was a prominent pro-growth strategy of the subregional economic development agency, which was targeting Londoners with placemarketing material that showed North Northamptonshire as less crowded, more rural, and attractive, and within reach of the capital ${ }^{\text {iv }}$. People challenged the framing of the area as a satellite of London, arguing that there was a shared interest across the subregion in preserving the character of places, supporting community building, and discouraging commuting. Responses to online questionnaire for instance stated that, "We do not want to encourage commuters to London who don't have time to get involved in community activities" and "areas of North Northamptonshire are beautiful idyllic areas to live in. Any housing increase needs to be in keeping and MUST NOT be allowed to destroy existing character, social communities or quality of life for current residents" (original emphasis). Such points might appear to reify the context of sub-regional planning, on the basis that the sub-region would need protecting from external influence. However, people were fundamentally seeking protection for localities and responding to a development strategy. 


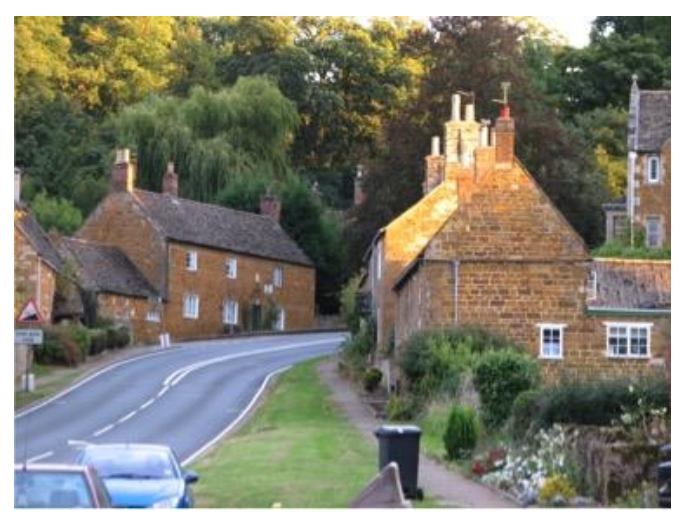

\section{Figure 7: A rural village in North Northamptonshire (Source: author)}

\section{Perspectives on scale}

This section discusses the different scales perceived in the case. Theoretical work underpinning the study suggested there could be two distinct rationalities for public involvement in spatial planning processes, and both rationalities were observed in the context and content of exchanges with the public (figure 8). The study confirmed that scale was constructed through ideas of shared interests, but people also made reference to the fixed scales that already existed within the context of statutory planning.

\begin{tabular}{|c|c|c|}
\hline & Participatory Rationale & Perceived Scale \\
\hline \multirow{3}{*}{ } & Inclusive & $\begin{array}{l}\text { National } \\
\text { - collection of regions }\end{array}$ \\
\hline & Inclusive & $\begin{array}{l}\text { Sub-national } \\
\text { - as a whole }\end{array}$ \\
\hline & Substantive & $\begin{array}{l}\text { Sub-regional } \\
\text { - collection of settlements }\end{array}$ \\
\hline \multirow{3}{*}{ 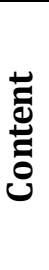 } & Substantive & $\begin{array}{l}\text { Local } \\
\text { - flexible }\end{array}$ \\
\hline & Inclusive & $\begin{array}{l}\text { Sub-regional } \\
\text { - collection of settlements }\end{array}$ \\
\hline & Inclusive \& Substantive & $\begin{array}{l}\text { Local } \\
\text { - within fixed boundaries }\end{array}$ \\
\hline
\end{tabular}

\section{Figure 8: Scalar perspectives (Source: author)}

Looking first at the context, multiple scales of shared interest were proposed. The government agenda of distributing growth presented a nationally shared interest, which set the scene for establishing statutory responsibilities and engaging communities. The notion of inclusive spatial planning (i.e. that ethical governance 
must involve those affected) underpinned the creation of processes 'fixed' at a range of sub-national scales. This included sub-regional planning for North Northamptonshire where growth was to be encouraged. The justification for strategy was managing growth in relation to the shared interests of the communities in that area. However, the set-up of participation also drew on substantive rationality (i.e. that public involvement has communicative learning value). Public engagement was promoted at the lowest tier of strategy-making, in order to understand detail of impacts on diverse settlements across the sub-region. The approach to engagement taken by the North Northamptonshire planners was therefore communicative, with discussions in settlements across the sub-region. It also opened up the possibility of discovering new scales of shared interests.

Turning to consider content, the participatory exchanges introduced more flexibility in perceived scales. The most prominent scale was the locality of the community. It tended to be smaller than the scope of the strategy, and centered on individual experiences of shared interests. However, the community view of issues expanded outwards from 'the backyard', and as a result could challenge the boundaries of the strategy. These perspectives on scale were disruptive. The social construction of scale opened up questions about statutory responsibilities for problems, and in theory this would be beneficial as it could initiate institutional reworking (Albrechts, 2013, 2015; Douglas, 1987; Forester, 1989, 1999). In this case, it increased dissatisfaction of citizens with what was at the time a relatively newly created planning authority. This calls to mind the warnings given about the possibility of 'endless openness' through communicative planning (Campbell and Marshall, 2002), which may stymie decision-making or actions to address urgent problems.

There were instances where the public engaged with the 'fixed' scales of the planning institutions. In particular, there were calls for fairness in distributing investment across settlements in the sub-region, and for protection from the 'external threat' of in-migration. Both of those suggested that the authority had a duty to act in the interest of the whole sub-region. However, people were also arguing that the interest of their own local community was at stake. The significance is that the scale of the community was probably not the same as the scale of the authority. The caveat here is that people were responding to strategy, rather than co-producing strategy (Cornwall, 2008). In any case, the scale of shared interest and the scale of state response would not be connected, which poses a challenge to applying Dewey's 
concept of the public interest in the context of spatial planning planning (1927). In light of the extra-boundary 'shared interests', this also calls into question the inclusive rationality, since empowerment may depend on the ability to influence an institution that (in the context of representative democracy) has no ethical duty towards some of the affected parties.

\section{Conclusions}

In conclusion, this study suggests that scale in participatory spatial planning is connected to understandings of shared interests, and that it would be a mistake to conflate the scale of decision-making with any particular scale of interest. Scale may determine the locality for formal participation, both in terms of who is involved and how that happens, but deliberation of shared interests will re-define the locality of interest. This can help identify problems that spatial planning might tackle, but it opens up new spaces of politics. Participation can bring new perspectives on scale, introducing fluidity and challenging the legitimacy of responsibilities. That is to say that there will be a range of public voices, which may relate to local place but are not fixed in alignment with institutions. Instead, local community issues relate to a fluid and wider-than neighbourhood area, and may call on state action over a scale that is beyond statutory boundaries. This fulfills the expectations of the communicative and social learning theory and is a scalar version of power struggles over different versions of a locality (Bond and Thompson-Fawcett, 2007; Colomb, 2017; Perrons and S., 2003). However, participants may also relate local issues to fixed areas of authorities, in a sense re-politicising those scales in their demands for spatial justice.

Two problems remain unresolved. The first is the issue of how to close down decisions and determine statutory responsibilities. Assuming either the substantive or the inclusive rationality for public involvement in spatial planning, voices from diverse places, as well as a range of social cohorts may need to be heard, and they may even include those from beyond statutory boundaries. The case looked at UK practice, where policy and regulation are separate elements at all scales within the regime (Natarajan, 2018), and thus spatial strategies are ultimately 'performed' (Janin Rivolin, 2008) (or not) via decisions on each development project as it comes forward to the decision-making stage. That is problematic because it is very possible that new 
perspectives might arise at the regulatory stage. More positively it gives the opportunity for flexibility and testing of assumptions e.g. about impacts that might affect the scale of protective planning measured that are needed.

The second problem is the disappointment of communities over a perceived distance between their interests and the scale of authority, which can undermine relationship building and lead to apathy towards participation. However, lessons of this study would suggest that contestations over scalar realities cannot be bracketed out planning processes. Briefly stated, the scale of community that should participate and the scale of state action cannot be simply derived. Instead, they should be explicit questions at all stages of spatial planning and participation.

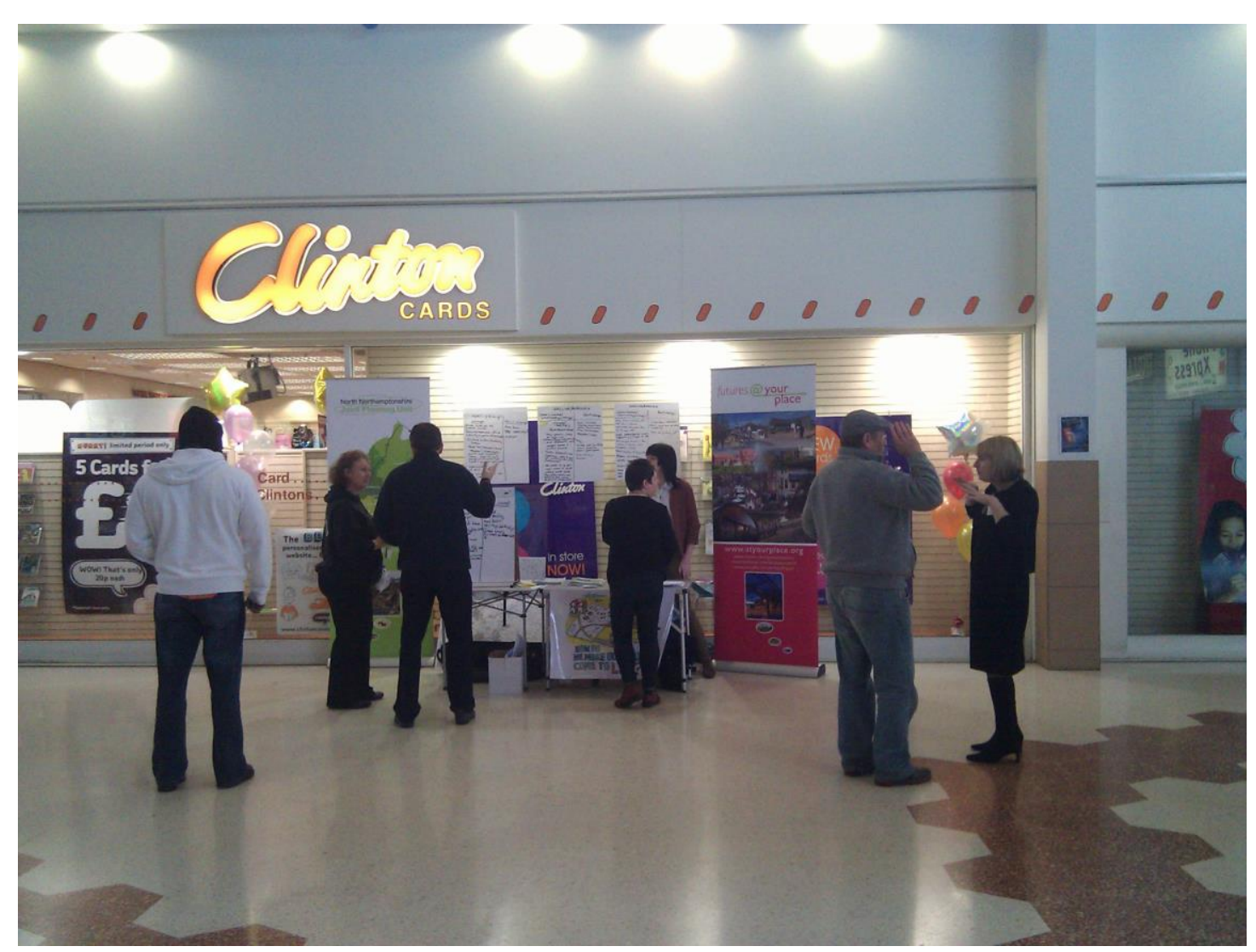

Figure 9: Roadshow in a shopping mall (Source: author)

\section{Acknowledgements}

I would like to thank the NNJPU, the participants from across North

Northamptonshire, and Professor Yvonne Rydin for their support during fieldwork, as well as Professor Malcolm Tait, Professor Maria Lee, and the anonymous reviewers for their support and advice. 


\section{References}

Albrechts, L. (2013), "Reframing strategic spatial planning by using a coproduction perspective", Planning Theory, Vol. 12 No. 1, pp. 46-63.

Albrechts, L. (2015), "Ingredients for a more radical strategic spatial planning", Environment and Planning B: Planning and Design, Vol. 42 No. 3, pp. 510525.

Allmendinger, P. and Haughton, G. (2007), "The fluid scales and scope of UK spatial planning", Environment and Planning A, Vol. 39 No. 6, pp. 1478-1496.

Allmendinger, P. and Haughton, G. (2010), "Spatial planning, devolution, and new planning spaces", Environment and Planning C: Government and Policy, Vol. 28 No. 5, pp. 803-818.

Baker, M., Hincks, S. and Sherriff, G. (2010), “Getting involved in plan making: Participation and stakeholder involvement in local and regional spatial strategies in England", Environment and Planning C: Government and Policy, Vol. 28 No. 4, pp. 574-594.

Baxter, P. and Jack, S. (2008), "The Qualitative Report Qualitative Case Study Methodology: Study Design and Implementation for Novice Researchers", The qualitative report, Vol. 13 No. 4, pp. 544-559.

Beebeejaun, Y. (2006), "The participation trap: The limitations of participation for ethnic and racial groups", International Planning Studies, Vol. 11 No. 1, pp. 3-18.

Beebeejaun, Y. (2016), "Exploring the intersections between local knowledge and environmental regulation: a study of shale gas extraction in Texas and Lancashire", Environment and Planning C: Government and Policy, Vol. 35 No. 3, pp. 417-433.

Bond, S. and Thompson-Fawcett, M. (2007), "Public Participation and New Urbanism : A Conflicting Agenda?", Planning Theory \& Practice, Vol. 8 No. 4, pp. 449-472.

Bouche-Florin, L.E. (2019), "Charter of participatory democracy: A call for action towards a balanced democratic system", Built Environment, Vol. 45 No. 1, pp. 112-129.

Brownill, S. and Parker, G. (2010), "Why bother with good works? The relevance of public participation(s) in planning in a post-collaborative era", Planning Practice and Research, Vol. 25 No. 3, pp. 275-282.

Campbell, H. and Marshall, R. (2002), “Utilitarianism's bad breath? A reevaluation of the public interest justification for planning", Planning Theory, Vol. 1 No. 2, pp. 163-187.

Colomb, C. (2017), "Participation and conflict in the formation of Neighbourhood Areas and Forums in 'super- diverse' cities", in Brownill, S. and Bradley, Q. (Eds.),Localism and neighbourhood planning: Power to the people?, Policy Press, Bristol, pp. 127-144.

Cornwall, A. (2004), "New Democratic Spaces? The Politics and Dynamics of Institutionalised Participation", IDS Bulletin, Vol. 35 No. 2, pp. 1-10.

Cornwall, A. (2008), “Unpacking 'Participation' Models, meanings and practices”, Community Development Journal, Vol. 43 No. 3, pp. 269-283.

Cornwall, A. and Coelho, V.S.P. (Eds.). (2006), Spaces for Change? The Politics of Participation in New Democratic Arenas, London, Zed Books. 
Cowell, R. (2017), "Decentralising energy governance? Wales, devolution and the politics of energy infrastructure decision-making", Environment and Planning C: Politics and Space, Vol. 35 No. 7, pp. 1242-1263.

Curry, N. (2012), "Community Participation in Spatial Planning: Exploring Relationships between Professional and Lay Stakeholders", Local Government Studies, Vol. 38 No. 3, pp. 345-366.

DCLG. (2013), "Historic first as neighbourhood plan is voted in by community", available at: https://www.gov.uk/government/news/historic-first-asneighbourhood-plan-is-voted-in-by-community.

Denzin, N.K. and Lincoln, Y.S. (2000), “The discipline and practice of qualitative research", Handbook of Qualitative Research, pp. 1-28.

Douglas, M. (1987), How Institutions Think, Routledge \& Keegan Paul, London.

Fainstein, S.S. (2010), The Just City, International Journal of Urban Sciences, Cornell University, New York, Vol. 18, doi:10.1080/12265934.2013.834643.

Fereday, J. and Muir-cochrane, E. (2006), “Demonstrating Rigor Using Thematic Analysis: A Hybrid Approach of Inductive and Deductive Coding and Theme Development", International Journal of Qualitative Methods, Vol. 5 No. March, pp. 1-11.

Flyvbjerg, B. (2001), Making Social Science Matter: Why Social Inquiry Fails and How It Can Succeed Again, (Sampson, S. (translator),Ed.)Southern Economic Journal, Cambridge University Press, Cambridge, Vol. 68, doi:10.2307/1061731.

Forester, J. (1989), Planning in the Face of Power, Journal of the American Planning Association, University of California Press, Berkeley, Vol. 48, doi:10.1080/01944368208976167.

Forester, J. (1999), The Deliberative Practitioner: Encouraging Participatory Planning Processes, MIT, Cambridge.

GOEM. (2009), "East Midlands Regional Plan March 2009”, TSO (The Stationery Office), London.

GOSE, GOEM and GOEE. (2005), "Milton Keynes \& South Midlands Sub-Regional Strategy", TSO (The Stationery Office), London.

Healey, P. (1996), "The communicative turn in planning theory and its implications for spatial strategy formation", Environment and Planning B: Planning and Design, Vol. 23 No. 2, pp. 217-234.

Healey, P. (2007), Urban complexity and spatial strategies: towards a relational planning for our times, (Hague, C., Richardson, T. and Upton, R.,Eds.), Routledge, London.

Healey, P. (2010), Making Better Places: The planning project in the twenty-first century, Palgrave Macmillan, Hampshire.

Hillier, J. (2003), “'Agon'izing Over Consensus: Why Habermasian Ideals cannot be 'Real'”, Planning Theory, Vol. 2 No. 1, pp. 37-59.

Holden, M. (2008), "Social learning in planning: Seattle's sustainable development codebooks", Progress in Planning, Vol. 69 No. 1, pp. 1-40.

Innes, J.E. (1995), “Planning Theory's Emerging Paradigm: Communicative Action and Interactive Practice", Journal of Planning Education and Research, Vol. 14 No. 3, pp. 183-189.

Innes, J.E. and Booher, D.E. (2010), Planning with complexity: an introduction to collaborative rationality for public policy, Routledge, London.

Janin Rivolin, U. (2008), "Conforming and Performing Planning Systems in 
Europe: An Unbearable Cohabitation", Planning Practice and Research, Vol. 23 No. 2, pp. 167-186.

Janssen-Jansen, L.B. and van der Veen, M. (2017), “Contracting communities: Conceptualizing Community Benefits Agreements to improve citizen involvement in urban development projects", Environment and Planning A, Vol. 49 No. 1, pp. 205-225.

Lee, M. (2017), "Knowledge and landscape in wind energy planning”, Legal Studies, Vol. 37 No. 1, pp. 3-24.

Lee, M., Armeni, C., de Cendra, J., Chaytor, S., Lock, S.J., Maslin, M., Redgwell, C., et al. (2013), "Public participation and climate change infrastructure", Journal of Environmental Law, Vol. 25 No. 1, pp. 33-62.

Lennon, M. (2016), “On 'the subject of plannings public interest”, Planning Theory, pp. 1-19.

Miraftab, F. (2004), "Invited and Invented Spaces of Participation: Neoliberal Citizenship and Feminists' Expanded Notion of Politics", Wagadu, Vol. 1, pp. 1-7.

Natarajan, L. (2017), "Socio-spatial learning: A case study of community knowledge in participatory spatial planning", Progress in Planning, Elsevier Ltd, Vol. 111, pp. 1-23.

Natarajan, L. (2018), "Major Wind Energy \& the Interface of Policy and Regulation: A Study of Welsh NSIPs", Planning Practice \& Research, Routledge, Vol. 34 No. 1, pp. 1-17.

Natarajan, L., Rydin, Y., Lock, S.J. and Lee, M. (2018), "Navigating the participatory processes of renewable energy infrastructure regulation: A 'local participant perspective' on the NSIPs regime in England and Wales", Energy Policy, Vol. 114, pp. 201-210.

NNJPU. (2008), "North Northamptonshire Core Spatial Strategy (adopted June 2008)", North Northamptonshire Joint Planning Unit.

ODPM. (2003), "Sustainable communities in the East Midlands: Building for the future", HMSO, London.

Perrons, D. and S., S. (2003), "Empowerment through Participation? Conceptual Explorarions and a Case Study", International Journal of Urban and Regional Research, Vol. 27 No. June, pp. 265-285.

Quick, K.S. and Feldman, M.S. (2011), "Distinguishing Participation and Inclusion”, Journal of Planning Education and Research, Vol. 31 No. 3, pp. 272-290.

Rittel, H.W.J. and Webber, M.M. (1973), "Dilemmas in a general theory of planning”, Policy Sciences, Vol. 4, pp. 155-169.

Rozema, J.G. (2015), 'Institutions and the social construction of 'missing links' in infrastructure planning”, Planning Theory and Practice, Routledge, Vol. 16 No. 4, pp. 479-497.

Rydin, Y., Natarajan, L., Lee, M. and Lock, S.J. (2018a), “Do local economic interests matter when regulating nationally significant infrastructure? The case of renewable energy infrastructure projects", Local Economy, Vol. 33 No. 3, pp. 269-286.

Rydin, Y., Natarajan, L., Lee, M. and Lock, S.J. (2018b), “Local voices on renewable energy projects: the performative role of the regulatory process for major offshore infrastructure in England and Wales", Local Environment, Vol. 23 No. 5, pp. 565-581. 
Sager, T. (2017), “Communicative planning”, in Gunder, M., Madanipour, A. and Watson, V. (Eds.),The Routledge Handbook of Planning Theory2, Routledge, London, pp. 93-108.

Sandercock, L. (2004), "Towards a Planning Imagination for the 21st Century”, Journal of the American Planning Association, Vol. 70 No. March 2015, pp. 133-142.

Slade, D., Gunn, S. and Schoneboom, A. (2019), Serving the Public Interest, London, doi:10.2139/ssrn.1592868.

Starman, A.B. (2013), "The case study as a type of qualitative research", Journal of Contemporary Educational Studies, Vol. 64 No. 1, pp. 28-43.

Tait, M. (2011), "Trust and the Public Interest in the Micropolitics of Planning Practice", Journal of Planning Education and Research, Vol. 31 No. 2, pp. 157171.

Tait, M. (2016), "Planning and the public interest: Still a relevant concept for planners?", Planning Theory, Vol. 15 No. 4, pp. 335-343.

TSO. (2011), Localism Act 2011, TSO (The Stationery Office), London, England, UK.

UNECE. (1998), “Aarhus Convention (UNECE Convention on Access to Information, Public Participation in Decision-making and Access to Justice in Environmental Matters)", UNECE, Aarhus, Denmark.

Wang, Y. (2015), "Negotiating the farmland dilemmas: 'barefoot planners' in China's urban periphery", Environment and Planning C: Government and Policy, Vol. 33 No. 5, pp. 1108-1124.

Watson, V. (2014), "Co-production and collaboration in planning - The difference", Planning Theory and Practice, Taylor \& Francis.

Wolsink, M. (2000), "Wind power and the NIMBY-myth: Institutional capacity and the limited significance of public support", Renewable Energy, Vol. 21 No. 1, pp. 49-64.

\footnotetext{
i Avoiding the more easily misread term 'participative rationale' used by Quick and Feldman.

${ }^{i i}$ During the period of study the 2008 version was in force, and a new version was adopted in 2016.

iii The Localism Act (TSO, 2011) removed England's regional tiers of planning, but the issue of growth remained and the population was projected to rise to at least 382,300 by 2031 (Office for National

Statistics estimates of 2011).

${ }^{\text {iv }}$ See https://www.youtube.com/watch?v=Lllnso3s1Ew
} 